\title{
Diagnosis of the Diatom Community upon Biofilm Development on Stainless Steels in Natural Freshwater
}

\author{
Caroline Richard, ${ }^{1}$ Smita Mitbavkar, ${ }^{2}$ and Jessem Landoulsi ${ }^{3,4}$ \\ ${ }^{1}$ Laboratoire de Mécanique et Rhéologie (LMR), EA 2640, Polytech'Tours, Université François Rabelais de Tours, \\ 37200 Tours, France \\ ${ }^{2}$ CSIR-National Institute of Oceanography, Dona Paula, Goa 403 004, India \\ ${ }^{3}$ Sorbonne Universités, UPMC Univ Paris 06, 75005 Paris, France \\ ${ }^{4}$ CNRS, UMR 7197, Laboratoire de Réactivité de Surface, 75005 Paris, France
}

Correspondence should be addressed to Caroline Richard; caroline.richard@univ-tours.fr and Jessem Landoulsi; jessem.landoulsi@upmc.fr

Received 26 January 2017; Accepted 13 April 2017; Published 25 May 2017

Academic Editor: David Alsteens

Copyright (C) 2017 Caroline Richard et al. This is an open access article distributed under the Creative Commons Attribution License, which permits unrestricted use, distribution, and reproduction in any medium, provided the original work is properly cited.

\begin{abstract}
This paper reports the development of biofilms on stainless steels (SS) upon exposure in a natural freshwater ecosystem for about six months and focuses on the composition of diatom populations. By using environmental scanning electron microscopy (ESEM) technique, we provide a detailed description regarding diatom identification at species level as well as their main characteristics, including type, morphology, ability to form colony, and motility. Results reveal the presence of both prostrate (initial colonizers) and stalked (late colonizers) forms. Pennate diatoms, Cocconeis placentula and Amphora coffeaeformis, and a centric diatom, Melosira varians, are shown to be the abundant forms regardless of the SS type. Pennate diatoms dominate the community and are directly attached to the substratum, whereas the centric form is entangled in the biofilm matrix in a significant number. The dominance of adnate forms suggests that these cells are sturdy and successfully maintaining their population. In situ monitoring of the electrochemical response of immersed materials showed ennoblement of the open circuit potential, which seems to be due to the biogenic production of $\mathrm{H}_{2} \mathrm{O}_{2}$, detected in a significant amount within the biofilms. The substantial enrichment of biofilms with diatoms potentially suggests the implication of these microorganisms in the process of ennoblement. A mechanism is proposed in this paper describing the possible interactions of diatom community with SS in the studied ecosystem.
\end{abstract}

\section{Introduction}

Diatoms are microscopic, unicellular, autotrophic algae which are members of the heterokontic group of cells and are responsible for a major portion of the primary productivity, thus forming the base of the food chain in aquatic ecosystems. Based on their morphology, two types of diatoms are identified, centric with a radial symmetry and pennate with a bilateral symmetry. In general, the centric types are abundant in the water column, whereas the pennate ones are found in biofilms formed on natural or artificial surfaces. This is due to their ability to attach to substrata via extracellular polymeric substances (EPS) which are secreted through a structure known as a raphe [1]. Depending on the positioning and number of raphes, pennate diatoms are classified as monoraphid (one raphe), biraphid (two raphes, both present on one valve or one on each valve), and araphid (no raphe). Some diatom species attach to substrata with the help of structures such as stalks or pads [2]. Both centric and pennate types are often observed in each other's habitats. As centric types do not possess raphes, they are found entangled within the biofilm community. Both forms occur as single cells or as colonies in various shapes (filaments, ribbons, fans, zigzags, or even stellate). Within the biofilms, these diatoms play a similar role as their counterparts in the water column forming the base of the benthic food webs. Although the role of diatoms as primary producers in aquatic environments is of major importance, their presence on artificial man-made structures is a serious issue. Diatom fouling may, indeed, greatly affect the performance of metallic 
TABLE 1: Standard designations and chemical composition (wt.\%) of stainless steel (SS) types used in this study.

\begin{tabular}{|c|c|c|c|c|c|c|c|c|c|c|}
\hline \multirow{2}{*}{ AISI designation } & \multirow{2}{*}{ ISO designation } & \multicolumn{9}{|c|}{ wt. $\%$} \\
\hline & & $\mathrm{C}$ & $\mathrm{Si}$ & $\mathrm{Mn}$ & $\mathrm{Cr}$ & $\mathrm{Ni}$ & Mo & $\mathrm{N}$ & $\mathrm{Cu}$ & $\mathrm{Fe}$ \\
\hline $304 \mathrm{~L}$ & $\mathrm{X} 2 \mathrm{CrNi18}-9$ & 0.022 & 0.18 & 1.34 & 18.20 & 8.15 & - & 0.094 & 0.075 & Balance \\
\hline $316 \mathrm{~L}$ & X2CrNiMo17-11-2 & 0.019 & 0.48 & 1.65 & 16.8 & 10.61 & 2.58 & 0.041 & 0.36 & Balance \\
\hline 254SMO & X1CrNiMoCuN20-18-17 & 0.020 & 0.80 & 1.00 & 20.00 & 18.00 & 6.25 & 0.020 & 0.75 & Balance \\
\hline
\end{tabular}

materials particularly used in structures located in marine and freshwater environments, resulting in huge economic loss. Diatom fouling on artificial substrata and strategies to prevent this process has been the subject of vast literature, especially in marine environments [3-13].

Stainless steels (SS) are among the most widely used materials in equipment having permanent or intermittent contacts with natural waters (seawater, freshwaters, estuaries, etc.). The exposure of SS to natural waters usually results in the increase (ennoblement) of the open circuit potential (OCP) which is largely attributed to the microbial activities within the biofilm [14-16]. The involvement of diatoms in the potential ennoblement is however not fully understood because diatom fouling communities and their role in microbiologically influenced corrosion (MIC) remain poorly documented (see review: [17] and references therein).

Diatoms are characterized by various growth forms described in terms of motility, colony, and extracellular mucilaginous matrix $[18,19]$. Each growth form has significant ecological implications resulting in different community structures which depend on the age of the biofilm and the environmental conditions. In the context of biofouling, understanding the individual behavior of diatoms at solid substrata is important for the design of antifouling surfaces. Information on diatom colonization on various types of substrata and biofilm age is available [1, 20-23]. Most of these studies have been conducted in marine environments, while investigations in natural freshwaters remain poorly documented [17]. Moreover, there is limited information regarding diatom communities and their growth forms in biofilms formed after long-term exposures [24], that is, after several months. These features are with primary importance as an antifouling surface may be efficient for "early stage" biofilms but not as effective for "long-term" biofilms.

This study was conducted with the aim of generating information on the diatom fouling communities on SS substrata from a freshwater habitat after a long-term exposure (about six months). The fouling diatom community is grouped based on the growth forms and their ecological implications are discussed. The impact of diatom fouling on the stability of SS surfaces is also examined by monitoring the electrochemical response of the materials in situ during the natural exposure.

\section{Experimental Procedures}

2.1. Natural Exposure. Austenitic (AISI 304L and AISI 316L) and superaustenitic (254SMO) stainless steel (SS) samples (Outokumpu, Stainless AB, Finland) were used for this study.
Their chemical compositions are given in Table 1. The SS surfaces were mechanically polished (both sides) with $\mathrm{SiC}$ papers of 600 and 1200 grain size to remove native oxides and other contaminants which may originate from material processing and to uniformize surface topography for all SS samples regardless of their type. After polishing, samples were rinsed with deionized water/ethanol $(1: 1, \mathrm{v} / \mathrm{v})$ in a sonication bath (70 W, $40 \mathrm{kHz}$, Branson, USA) and dried under nitrogen gas flow. The natural exposure tests were conducted in the period of July to January by immersing SS samples in the Oise River (Verberie site located in the north of France, see Table 2 for more details) at a depth of about $1.50 \mathrm{~m}$.

2.2. In Situ OCP Monitoring. During the natural exposure, the electrochemical behavior of SS samples was monitored continuously for about 40 days. For this purpose, the open circuit potential (OCP) of the SS electrodes was recorded in situ using a holder designed specifically for the experiment (see Figure S1 in Supplementary Material available online at https://doi.org/10.1155/2017/5052646). It includes 20 SS samples and 5 reference electrodes (saturated calomel electrode (SCE)) placed at equal distances with respect to the SS working electrodes (i.e., one reference electrode for four SS samples). The SS samples were fixed to the holder at both sides, as shown in Figure S1. At one side, the electric contacts between SS specimens and copper wires were embedded in an epoxy resin (Epofix, Struers, Denmark). At the other side, the samples were maintained by a Teflon holder. Data recording was performed using a multiplexer (Agilent 34970A) equipped with BenchLink DataLogger ${ }^{\circledR}$ software, which allows the OCP values to be measured every $10 \mathrm{~min}$.

2.3. Surface Characterization. After natural exposure, the SS surfaces were rinsed with distilled water and dried under gentle nitrogen gas flow. Microscopic observations of SS surfaces were carried out without any preliminary chemical treatment using an environmental scanning electron microscope (ESEM, FEI Quanta FEC 250, FEI, USA). ESEM images were recorded on, at least, three different samples for each SS type. Diatom species identification was performed using micrographs, on the basis of flora reference [2, 25-28].

The surface composition of SS samples was determined by means of energy-dispersive X-ray spectroscopy (EDX) analyses performed using PGT IMIX-PTS apparatus (FEI, USA).

To provide a rough estimate of biofilm thicknesses, after natural exposure, SS samples were rinsed with deionized water, dried with nitrogen gas flow, and coated with epoxy 
TABLE 2: Mean parameters of freshwater (Verberie site, Oise river, France).

\begin{tabular}{lccc}
\hline Parameter & Unit & Data & Standard deviation \\
\hline $\mathrm{pH}$ & - & 7.96 & 0.19 \\
Temperature & ${ }^{*} \mathrm{C}$ & 13.72 & 5.87 \\
Conductivity at $25^{\circ} \mathrm{C}$ & $\mu \mathrm{S} \cdot \mathrm{cm}^{-1}$ & 617.64 & 59.38 \\
Turbidity & $\mathrm{NTU}$ & 21.92 & 21.84 \\
Total suspended matter & $\mathrm{mg} \cdot \mathrm{L}^{-1}$ & 27.88 & 26.95 \\
COD & $\mathrm{mg} \cdot \mathrm{L}^{-1}$ & 15.67 & 6.82 \\
Redox potential & $\mathrm{mV}$ & 160.17 & 26.57 \\
BOD5 at $20^{\circ} \mathrm{C}$ & $\mathrm{mg} \cdot \mathrm{L}^{-1}$ & 2.08 & 0.83 \\
Dissolved oxygen & $\mathrm{mg} \cdot \mathrm{L}^{-1}$ & 10.36 & 1.55 \\
Chloride $\left[\mathrm{Cl}^{-}\right]$ & $\mathrm{mg} \cdot \mathrm{L}^{-1}$ & 29.00 & 7.38 \\
Bicarbonate $\left[\mathrm{HCO}_{3}{ }^{-}\right]$ & $\mathrm{mg} \cdot \mathrm{L}^{-1}$ & 280.17 & 25.90 \\
Carbonate $\left[\mathrm{CO}_{3}{ }^{2-}\right]$ & $\mathrm{mg} \cdot \mathrm{L}^{-1}$ & 2.62 & 0.49 \\
Phosphate $\left[\mathrm{PO}_{4}{ }^{3-}\right]$ & $\mathrm{mg} \cdot \mathrm{L}^{-1}$ & 0.5 & - \\
Nitrate $\left[\mathrm{NO}_{3}{ }^{-}\right]$ & $\mathrm{mg} \cdot \mathrm{L}^{-1}$ & 17.14 & 3.71 \\
Nitrite $\left[\mathrm{NO}_{2}{ }^{-}\right]$ & $\mathrm{mg} \cdot \mathrm{L}^{-1}$ & 0 & 0 \\
Sulfate $\left[\mathrm{SO}_{4}{ }^{2-}\right]$ & $\mathrm{mg} \cdot \mathrm{L}^{-1}$ & 38.17 & 6.18 \\
Na & $\mathrm{mg} \cdot \mathrm{L}^{-1}$ & 17.00 & 7.50 \\
Mg & $\mathrm{mg} \cdot \mathrm{L}^{-1}$ & 11.13 & \\
Silica $\left(\mathrm{SiO}_{2}{ }^{-1}\right.$ & $\mathrm{mg} \cdot \mathrm{L}^{-1}$ & 4.25 & \\
Chlorophyll a & $\mu \mathrm{m} \cdot \mathrm{L}^{-1}$ & \\
\hline
\end{tabular}

${ }^{*}$ Data based on three-year average from the French Water Agency for Seine-Normandy Water (http://www.eau-seine-normandie.fr).

resin to set the SS/biofilm interface immobilized. The samples were then cross-sectioned, polished, and thoroughly rinsed for ESEM observations.

\subsection{Detection of Hydrogen Peroxide $\left(\mathrm{H}_{2} \mathrm{O}_{2}\right)$ within the Biofilm.} The presence of $\mathrm{H}_{2} \mathrm{O}_{2}$ within biofilms formed on SS surfaces after an exposure of about 1, 3, and 6 months in the natural medium was checked using analytical test papers (Merck no. 1.10011.0001). This method provides semiquantitative information regarding the amount of $\mathrm{H}_{2} \mathrm{O}_{2}$ present within the biofilm for concentrations ranging from 1 to $100 \mathrm{mg} \mathrm{L}^{-1}$.

\section{Results}

3.1. Biofilm Formation on SS Surfaces. Typical ESEM micrographs of SS surfaces after about a six-month exposure in the natural river revealed the presence of heterogeneous biofilms (Figure 1). The enrichment of biofilms with diatom community is obvious in all the micrographs, regardless of the SS type (Figure 1). The morphological heterogeneous nature of biofilms was reflected in the degree of coverage of the SS surfaces. In some cases, the biofilm did not cover the SS surface totally, as evidenced by the stripes due to polishing, and, in other cases, a thick and dense film was observed which almost totally covered the SS surface (Figures 1(c), 1(d), and $1(\mathrm{f}))$. The biofilm thicknesses estimated in the dried state are around $20 \mu \mathrm{m}$ but may significantly vary along the SS/biofilm interface, as shown in Figure 2. However, it must be kept in mind that drying causes a significant loss of water content of the biofilm and, probably, morphological changes, leading to an underestimation of its thickness. Noticeable variations of the biofilm thickness were observed on the different SS samples, but no clear trend can be established as a function of the SS type (Figures 2(b)-2(d)).

Regarding the chemical composition of biofilms, a particular interest was dedicated to the presence of $\mathrm{H}_{2} \mathrm{O}_{2}$, owing to its ability to alter the stability of SS (for more details, see Section 4). It is worth remembering that the analytical paper test used for $\mathrm{H}_{2} \mathrm{O}_{2}$ is usable for $\mathrm{H}_{2} \mathrm{O}_{2}$ concentrations ranging from 1 to $100 \mathrm{mg} \mathrm{L}^{-1}$ (Figure S2 in Supplementary Material). As a control, the analytical test paper wetted in the natural river remained uncolored, indicating that the amount of $\mathrm{H}_{2} \mathrm{O}_{2}$ was below the detection limit in the ambient freshwater. In contrast, all the tests conducted on the biofilms were positive and reproducible, showing a concentration in the order of $100 \mathrm{mg} \mathrm{L}^{-1}$ at different exposure times (1, 3, and 6 months), thus confirming the presence of a significant concentration of $\mathrm{H}_{2} \mathrm{O}_{2}$ within the biofilms (Figure S2). This result is in agreement with previous studies conducted both in seawater [29] and in natural rivers [30].

Further surface characterizations were performed on SS surfaces after their immersion in the natural medium using EDX analyses. A representative spectrum recorded on a SS sample is shown in Figure 3. Despite the heterogeneous nature of biofilms, EDX spectra showed similar pattern, revealing the presence of elements originating from the SS substratum, including bulk and oxide layer $(\mathrm{Fe}, \mathrm{Cr}, \mathrm{Ni}, \mathrm{O}$, etc.), salts, and organic compounds. More importantly, EDX spectrum revealed the dominating presence of silicon $(\mathrm{Si})$, present in a small amount in the SS bulk (Table 1), which mainly originates from the diatom frustules (Figure 3 ). The intensity of Si peak varied slightly from one analyzed zone to 


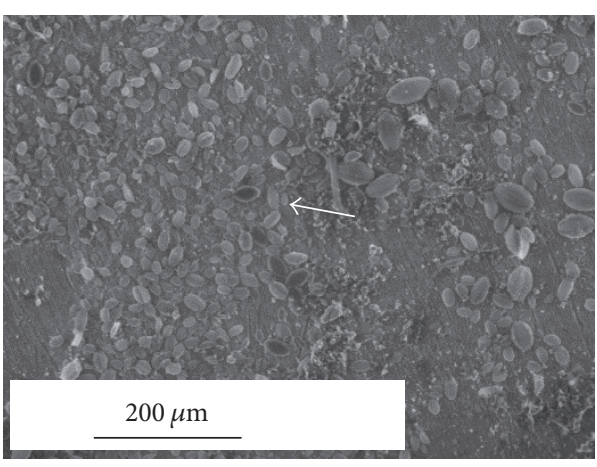

(a)

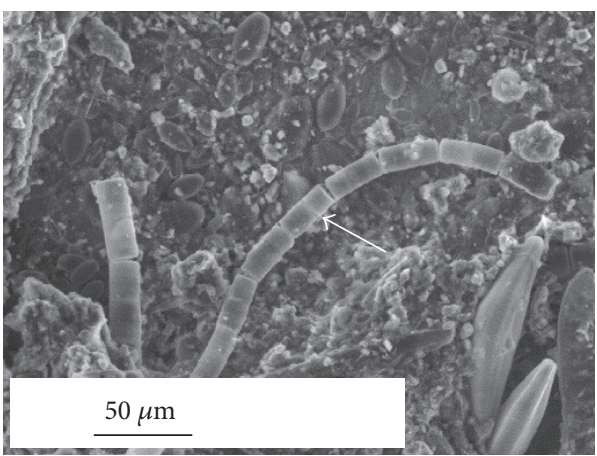

(c)

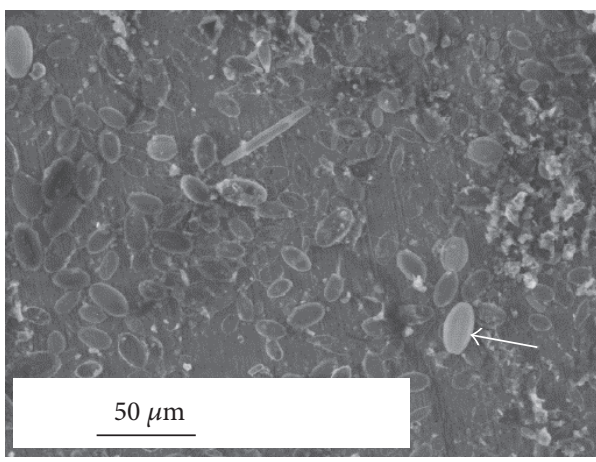

(e)

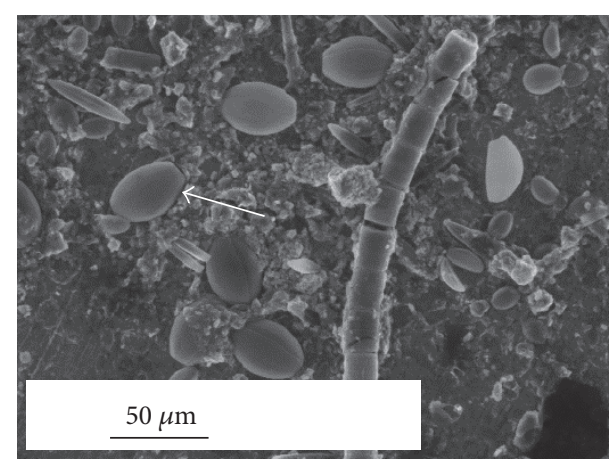

(b)

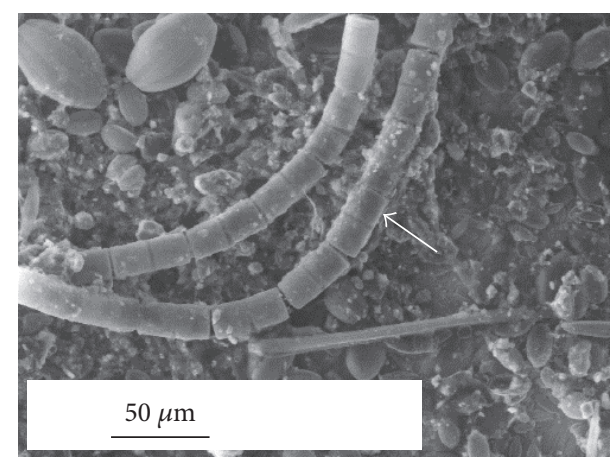

(d)

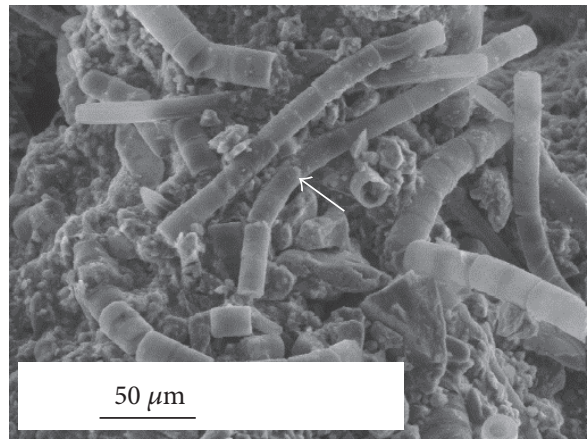

(f)

FIGURE 1: Representative ESEM micrographs showing diatom colonization on different types of SS (304L, 316L, 254SMO) exposed for six months in the natural river. Arrows in plates indicate Cocconeis placentula dominated community on 304L SS ((a), (b)), Melosira varians and other pennate diatoms dominated on 316L SS ((c), (d)), C. placentula dominated community (e), and M. varians dominated community on 254SMO SS (f). Horizontal line indicates the scale bar (50 and $200 \mu \mathrm{m})$.

another and from one sample to another (data not shown), but the trend remained almost the same with a significant amount of silicon in the presence of diatoms.

3.2. Fouling Diatom Community. A thorough examination of ESEM images allowed the identification of dominant diatom growth forms and species to be made. Nine diatom species were encountered on the SS surfaces: one centric and eight pennate species (Table 3). The pennate diatoms were attached to the substratum and included Cocconeis placentula, Amphora ovalis, Gyrosigma sp., Placoneis elginensis, and Nitzschia sigmoidea (Figures 4(a)-4(h)). Another rosette type pennate diatom, Synedra ulna, was observed with individual cells held together by small mucilage pads produced at the poles of the valves leading to the formation of colonies due to common attachment on the substratum (Figure 5(a)). Rhoicosphenia abbreviata occurred as a stalked pennate diatom, whereas Cymbella sp. was directly attached to the substratum (Figures 5(b) and 5(c)). The only centric form, Melosira varians, was encountered in high numbers as a filamentous and unattached species (Figures 5(f) and 5(g)).

A detailed analysis of ESEM images reveals the influence of the SS type on the composition of the diatom communities (Table 4). It appears, indeed, that pennate diatoms, C. placentula and A. coffeaeformis, and the centric diatom, $M$. varians (Table 4 and Figure 1), were the abundant forms representing 


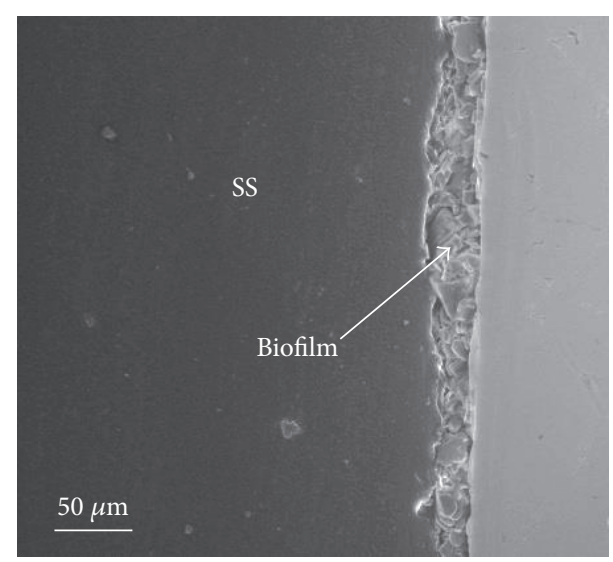

(a)

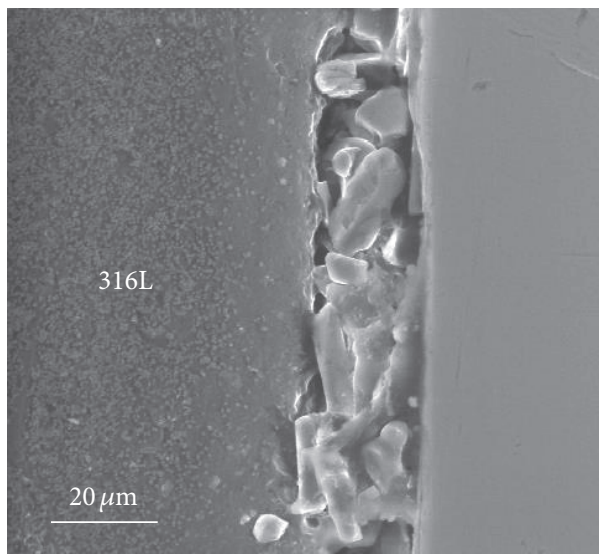

(c)

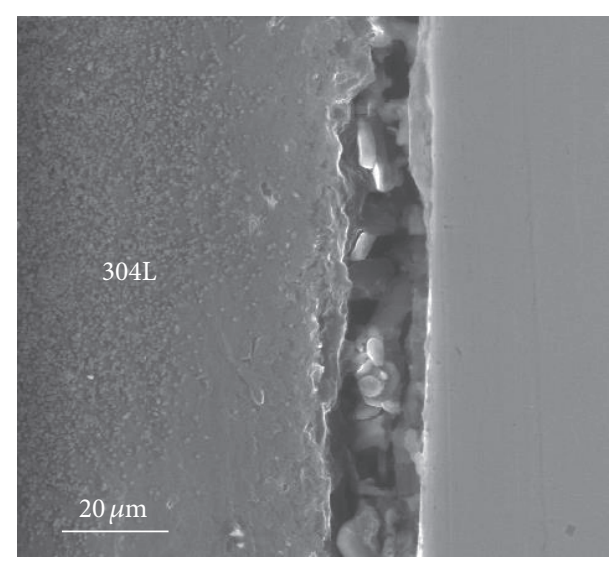

(b)

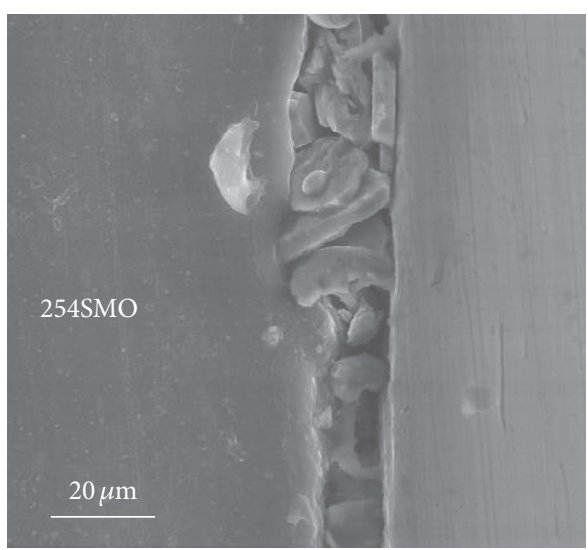

(d)

FIGURE 2: Representative ESEM images recorded on SS samples showing the thickness of biofilms formed on ((a), (b)) 304L (at different magnitudes), (c) 316L, and (d) 254SMO SS.

TABLE 3: Taxonomic list of diatoms present on the stainless steel after immersion in the natural freshwater for about six months.

\begin{tabular}{lccccc}
\hline Class & Type & Species & Solitary/colonial & Form & Raphe \\
\hline Coscinodiscophyceae & Centric & Melosira varians Agardh (1827) & Chain colony & Floating & Araphid \\
Bacillariophyceae & Pennate & Amphora ovalis Kutzing (1844) & Solitary cell & Adnate & Biraphid \\
Bacillariophyceae & Pennate & Cocconeis placentula Ehrenberg (1838) & Solitary cell & Adnate & Monoraphid \\
Bacillariophyceae & Pennate & Cymbella sp. Agardh & Arbuscular colony & Mucilage stalk-upright & Biraphid \\
Bacillariophyceae & Pennate & Gyrosigma sp. Hassall & Solitary cell & Motile & Biraphid \\
Bacillariophyceae & Pennate & Nitzschia sigmoidea W. Smith (1853) & Solitary cell & Motile & Biraphid \\
Bacillariophyceae & Pennate & Placoneis elginensis (Gregory) Cox (1987) & Solitary cell & Motile & Biraphid \\
Bacillariophyceae & Pennate & Rhoicosphenia abbreviata (Agardh) & Arbuscular colony & Mucilage stalk-upright & Biraphid \\
Fragilariophyceae & Pennate & Synedra ulna Ehrenberg (1836) & Rosette colony & Mucilage stalk-upright & Araphid \\
\hline
\end{tabular}

the fouling diatom community on all three SS types. However, while both the pennate and centric species were dominant on 316L and 254SMO types, only pennate species were dominant on 304L. Among 316L and 254SMO, M. varians was dominant on the former substrata (Table 4 and Figure 1).

3.3. Evolution of Open Circuit Potential. One relevant way to evaluate the behavior of SS upon natural exposure is to record their open circuit potential (OCP). This method has the advantages to be noninvasive and to record events in situ, that is, during the colonization of microorganisms and the development of the biofilm. Typical evolutions of OCP recorded on the different SS types are given in Figure 6. Results revealed a significant increase of OCP towards positive values, higher than $+200 \mathrm{mV} / \mathrm{SCE}$ after about ten days of immersion. The trends observed on 304L (Figure 6(a)), on 316L (Figure 6(b)), and on 254SMO (Figure 6(c)) samples were similar, and the potential fluctuations generally exhibited low amplitude 


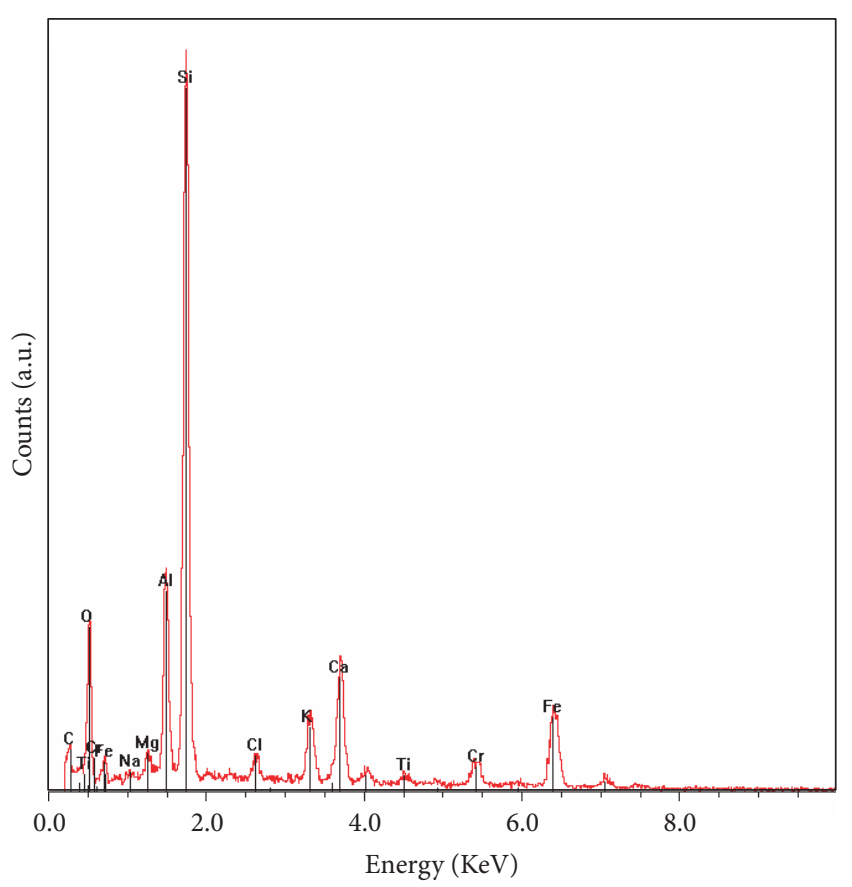

FIGURE 3: Representative EDS pattern recorded on SS sample after a six-month exposure in the natural river.

(few $\mathrm{mV}$ ). Moreover, the ennoblement either was immediate or occurred after some days (less than 5 days). In natural freshwaters, this delay, called "latency time," has been already observed and seems to be mainly due to the variation of the water temperature which influences the biofilm development on SS surfaces and its microbial activities [30]. However, the phenomenon remains not well understood as many controversies regarding its origin are reported in the literature. This is indeed related to the complexity of natural rivers and the large variations from one location to another, in terms of composition and physicochemical parameters, which make any attempt of generalization difficult. Nevertheless, our results clearly support the hypothesis of a systematic OCP increase in natural rivers, sometimes contradicted (see [16] and references therein), independently of the SS composition (Table 1) and their microstructure (austenitic versus superaustenitic).

\section{Discussion}

It is obvious that diatoms are important in the biofouling community that develops on SS and other artificial substrata in natural freshwaters. In spite of its importance, diatom populations remain poorly documented compared to other microorganisms, namely, bacteria, especially in studies dealing with potential ennoblement $[17,30,31]$. In the present study, the immersion of SS substrata in the natural river for about six months led to the development of heterogeneous biofilms highly enriched with diatoms. This is the first report of long-term (i.e., several months) fouling diatom community on SS substrata from a freshwater ecosystem and its potential role in the electrochemical behavior of SS.
The dominance of pennate diatoms in the fouling film is a ubiquitous observation [9] due to their ability to attach to any surface. In previous studies, various growth forms of the attached diatom community have been described in terms of motility, colony form, and extracellular mucilaginous matrix form [32]. They are grouped into loosely attached motile forms, adnate (attaching with discs) and with short and long stalks. In the process of diatom fouling, a sequence is usually observed based on the appearance of the growth forms. Generally, raphid diatoms are among the earliest and most abundant primary colonizers of natural and artificial surfaces [32]. Cells adhere prostrate on the substratum, with the entire cell remaining close to the substratum surface [33]. These diatoms belong to the group of "tightly attached alga" including forms that grow oppressed to the substratum. C. placentula and $A$. ovalis belong to this group of diatoms. Furthermore, they are slow-moving solitary forms and are both epi- or endopsammic [18]. They have strong attachment capabilities [34], even under low light intensities [35], and tolerate darkness and anoxia for several days [36]. Also, heterotrophy is common among benthic diatoms [37]. These adaptations are important for prostrate, slow-moving cells subjected to frequent smothering or burial by other cells, detritus, and sediment [38]. C. placentula is tolerant of moderate, but not severe, organic pollution and is a good indicator of eutrophication [39]. Members of these genera have been reported from toxic [33] and nontoxic [20, 21] surfaces.

The motile forms are followed by stalked diatoms which raise themselves from the surface and thus better utilize the vertical dimension. These nonmotile colonial forms can be subdivided according to the vertical expansion of the colonies over the substratum (Table 3 ). With respect to the genera encountered on the SS surfaces, in ascending order of uprightness are the linear chains (Melosira), arborescent forms (Cymbella and Rhoicosphenia), and fan-shaped colonies (Synedra). Synedra is known to possess high adhesive strength [40]. Rhoicosphenia is an indicator of eutrophication and pollution [39]. Cymbella is an asymmetrical biraphid diatom with cells growing predominately in benthic habitats and often producing mucilaginous stalks that are secreted through the apical pore field (Figures 5(d) and 5(e)). Members of these stalked diatom genera have been reported from toxic [24] and nontoxic [20,21] surfaces. $M$. varians represents the nonmotile form with high light requirements [41, 42] and has been widely associated with eutrophic conditions (Figures 5(f) and 5(g)). These filamentous and unattached species are bottom-living centric forms that lack attachment mechanisms and maintain their position in flowing water through entanglement with species that attach to substrata with mucilaginous stalks [24]. In tropical estuarine waters, the centric species, Melosira nummuloides, and the pennate genera, Navicula and Amphora, have been reported to be the dominant forms encountered on SS surfaces [20, 43].

The success of each diatom species in the fouling community depends on the endurance of its growth form in response to the environmental conditions. The prostrate growth form and firm attachment via extracellular polymeric substances secreted by the raphe make C. placentula relatively resistant to 


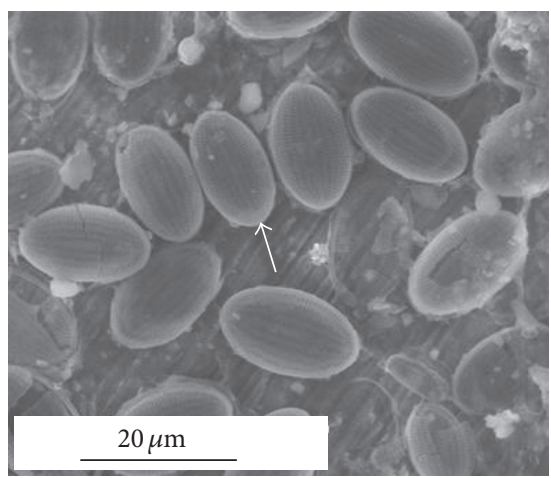

(a)

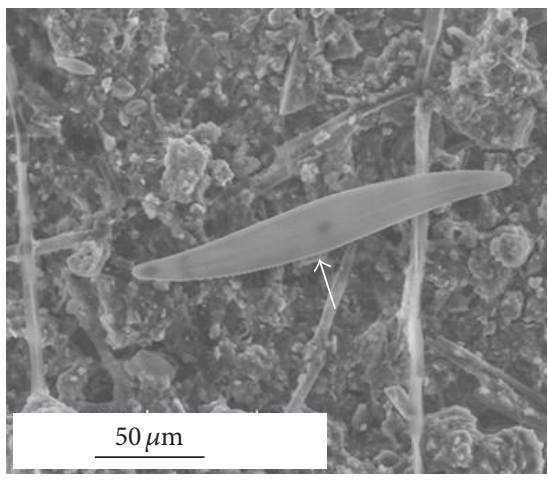

(c)

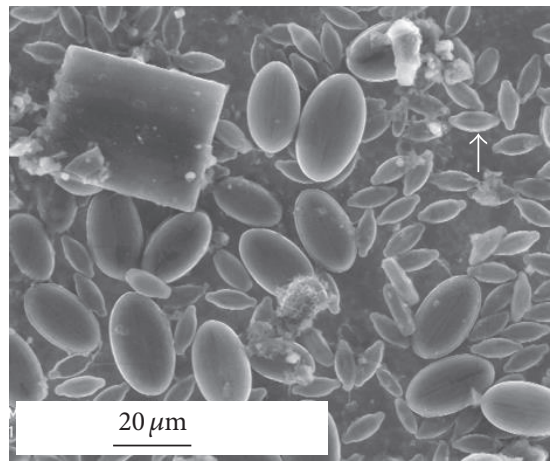

(e)

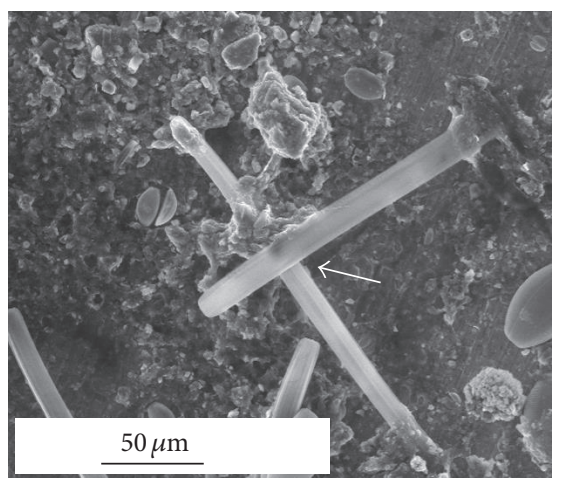

(g)

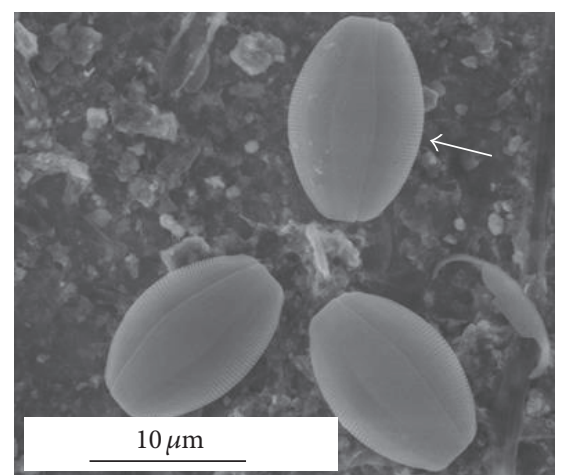

(b)

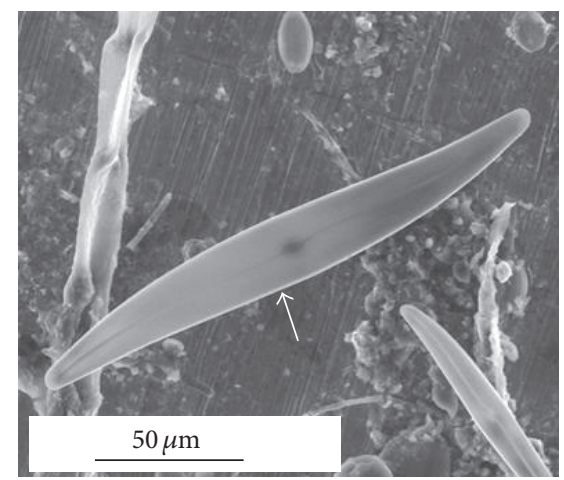

(d)

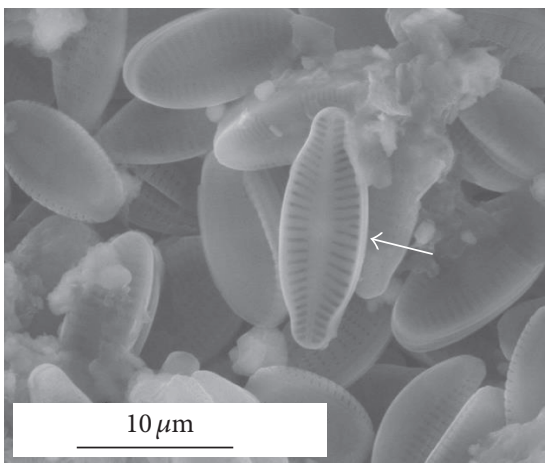

(f)

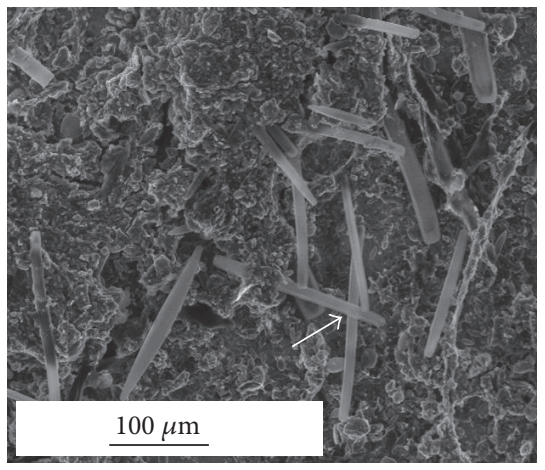

(h)

FIGURE 4: ESEM micrographs showing the diatom species composition present on the SS specimens after a six-month exposure period in the natural river: arrows in plates ((a) to (f)) indicate Cocconeis placentula (a), Amphora ovalis (b), Gyrosigma sp. ((c), (d)), Placoneis elginensis along with other pennate diatoms ((e), (f)), and Nitzschia sigmoidea are embedded in the biofilm matrix ((g), (h)). Horizontal line indicates the scale bar $(10,20,50$, and $100 \mu \mathrm{m})$. 


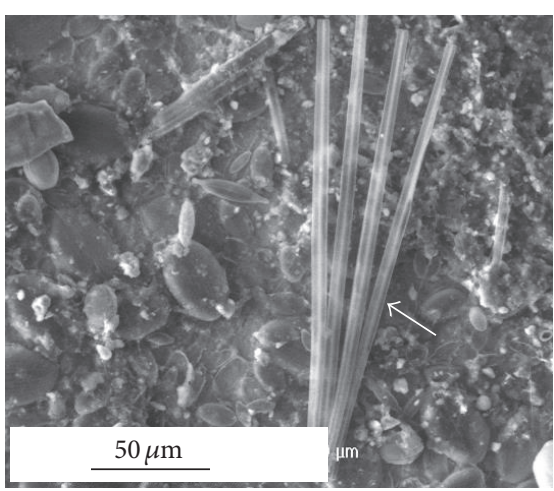

(a)

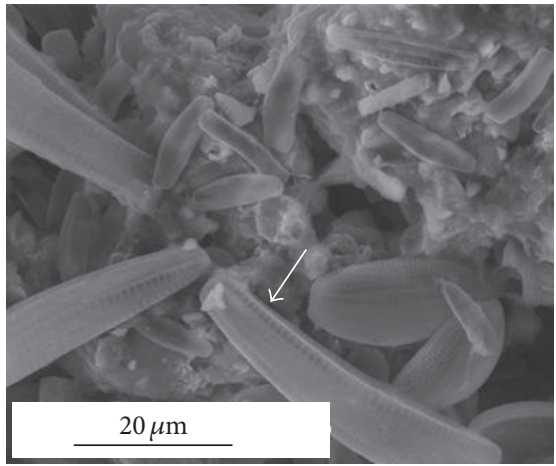

(c)

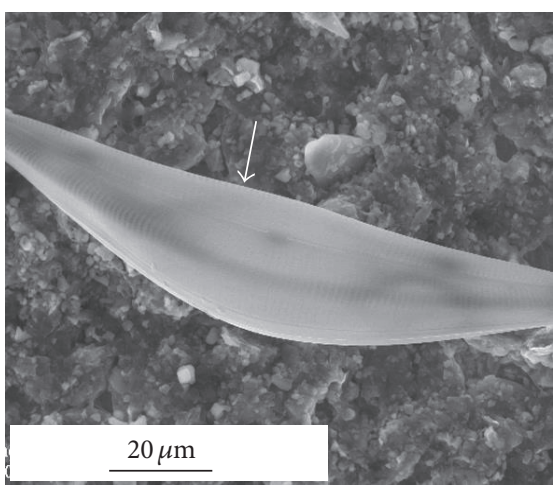

(e)

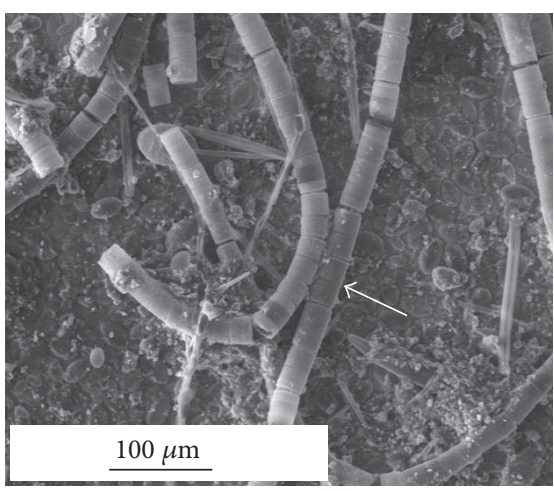

(g)

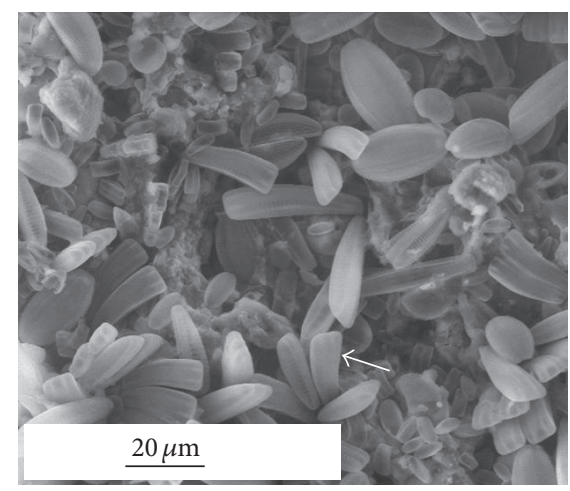

(b)

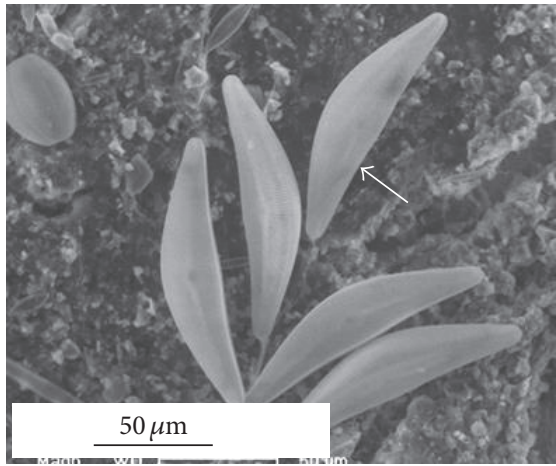

(d)

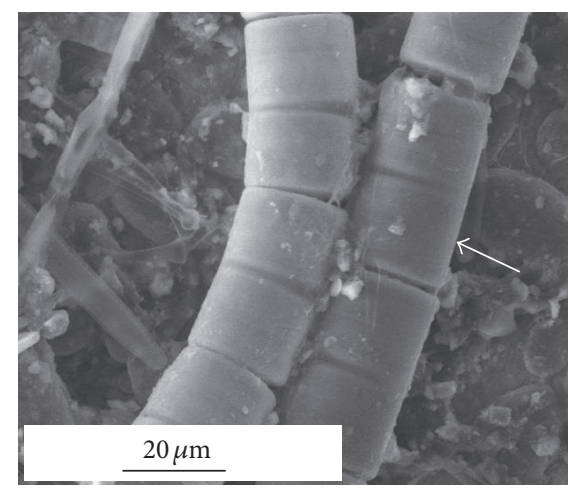

(f)

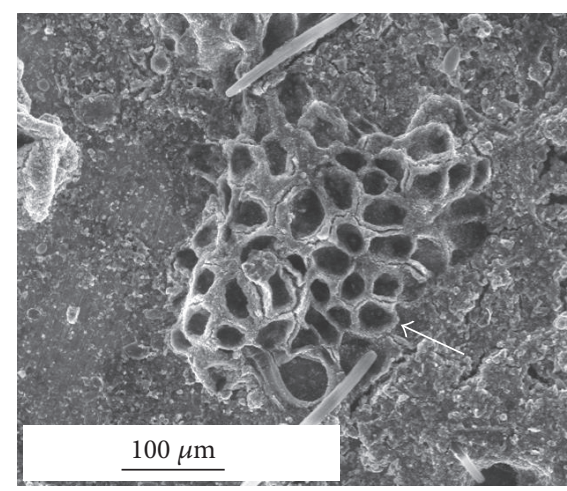

(h)

FIGURE 5: ESEM micrographs showing the composition of diatom species present on the SS specimens after a six-month exposure period in the natural river: arrows in plates ((a) to (h)) indicate the presence of Synedra ulna (a), Rhoicosphenia abbreviata along with other pennate diatoms ((b), (c)), Cymbella sp. ((d), (e)), chains of Melosira varians ((f), (g)), and Spongia (h). Horizontal line indicates the scale bar (20, 50, and $100 \mu \mathrm{m})$. 
TABLE 4: Relative abundance of diatom species on the different SS types (“-" = absent; “+” = low; "++" = moderate; “+++" = high; “++++" = very high).

\begin{tabular}{lccc}
\hline Species & $304 \mathrm{~L}$ & $316 \mathrm{~L}$ & \\
\hline Melosira varians & ++ & +++ & ++ \\
Amphora ovalis & +++ & ++++ & ++++ \\
Cocconeis placentula & + & + & +++ \\
Cymbella sp. & + & + & ++++ \\
Gyrosigma sp. & ++ & + & + \\
Nitzschia sigmoidea & - & + & + \\
Placoneis elginensis & + & + \\
Rhoicosphenia abbreviata (Agardh) & - & + \\
Synedra ulna & & + \\
\hline
\end{tabular}

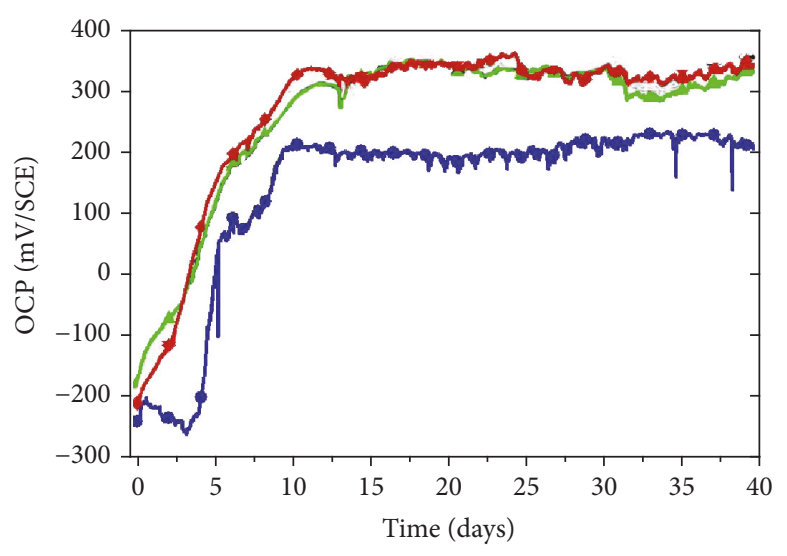

(a)

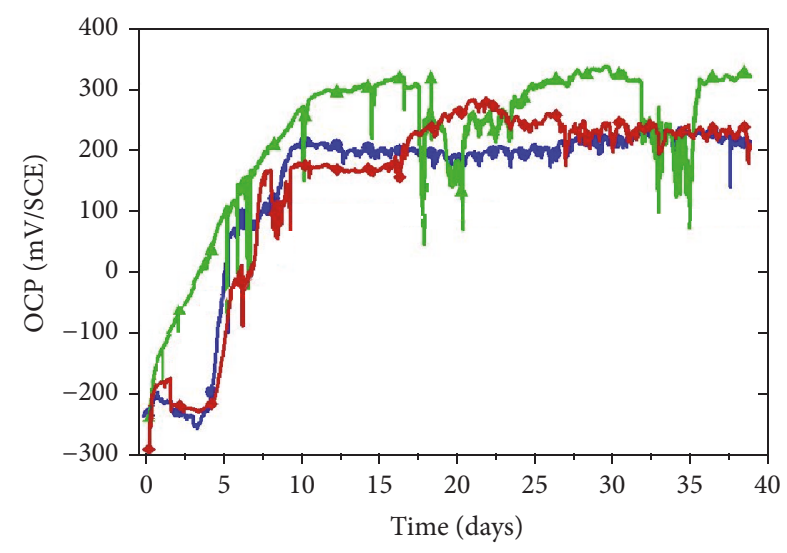

(b)

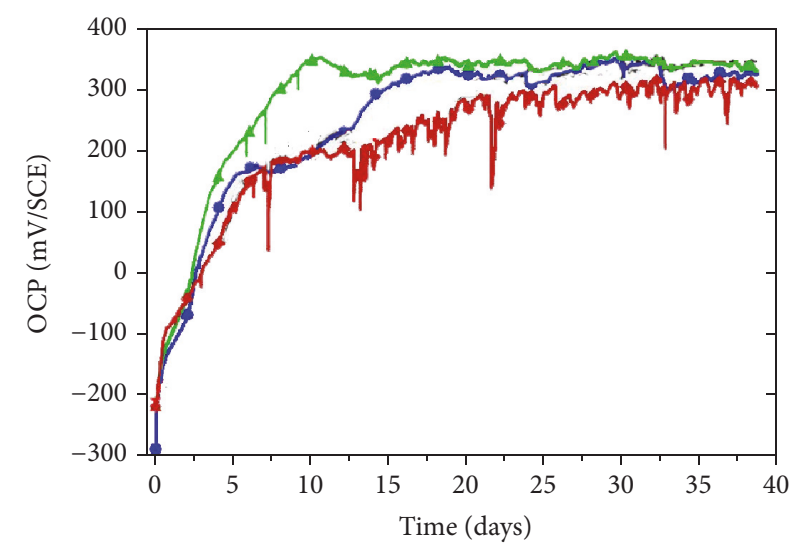

(c)

FIGURE 6: Typical OCP evolution recorded on different SS samples upon exposure in the natural river: (a) 304L and (b) 254SMO SS types.

scour and to selective grazers $[44,45]$. The relative abundance of $C$. placentula was found to be high under strong current speed in rivers [46]. This species has the ability to complete its entire life cycle tightly attaching to the substratum surface, thereby avoiding shear forces that are experienced by other species that occupy a more elevated position from the surface [33]. The stalked diatoms have an advantage of acquiring nutrients from the surrounding waters due to their height as compared to the ones lying flat at the bottom. The first colonizers may be photoinhibited by the shading caused by the stalks and the cells at their tops and also nutrient limited [32]. The presence of the adnate forms in the six-monthold diatom community suggests that these cells were sturdy and hence were successful in maintaining their population. ESEM observations evidenced that diatoms may be present at different locations in the direction perpendicular to the SS 
surface plane. They were placed in close contact to "bare" SS surface, embedded within the biofilm, or also present on the top of the biofilm (Figures 1, 4, and 5).

Regarding the electrochemical behavior of SS upon natural exposure, the potential ennoblement was observed on all SS types (Figure 6). It was concomitant with the significant presence of $\mathrm{H}_{2} \mathrm{O}_{2}$ within biofilms. Earlier studies have identified $\mathrm{H}_{2} \mathrm{O}_{2}$ as one of the main intermediates of the oxygen reduction reaction within both marine and freshwater biofilms formed on SS substrata [29, 30, 47-49]. Furthermore, the nature of electrochemical processes involving $\mathrm{H}_{2} \mathrm{O}_{2}$ has been deeply investigated on SS in laboratorycontrolled systems using natural sterilized seawater [5053], artificial seawater [50-52], and artificial freshwater [30, $54,55]$. The desired concentration of $\mathrm{H}_{2} \mathrm{O}_{2}$ was obtained either through addition of a $\mathrm{H}_{2} \mathrm{O}_{2}$ solution or by in situ production through an enzyme-catalyzed reaction to mimic the microbial generation of $\mathrm{H}_{2} \mathrm{O}_{2}$ in biofilms. The biogenic formation of $\mathrm{H}_{2} \mathrm{O}_{2}$ is mainly controlled by enzyme-catalyzed reactions both for production (enzymes using $\mathrm{O}_{2}$ as electron acceptors) or for degradation (enzymes involved in processes against oxidative stress) [16]. The amount of $\mathrm{H}_{2} \mathrm{O}_{2}$ within biofilms is also affected by diffusion at the interface of SS/biofilm/solution which is generally influenced by the biofilm morphology, hydrodynamic effects, temperature changes, and so forth.

The large enrichment of the SS biofilms with diatoms may suggest a possible implication of these microalgae in the process of ennoblement. In the present study, this hypothesis is supported by the fact that OCP values measured after three and six months remain relatively high, that is, ranging from +200 to $+360 \mathrm{mV} / \mathrm{SCE}$. Indeed, an analysis of data reported in the literature [17] reveals the possibility of different mechanisms, involving diatoms: action through (i) photosynthetic activities and (ii) via bacteria-diatom interaction. The most relevant evidence regarding the photosynthetic activities relies on the light-dependent ennoblement [30, 48, $56,57]$. The photosynthetic metabolic activity, which leads to the production of $\mathrm{O}_{2}$ at the SS/biofilm interface, seems to induce only day-night variations that do not prevent the potential ennoblement. This may explain why ennoblement also occurred in dark conditions. In the present study, on some SS samples, periodic potential fluctuations were observed and may correspond to day/night cycles (Figure 6). However, the amplitudes of variation were lower compared to previous reports $[30,48]$. These day/night potential variations can be attributed to enrichment/depletion cycles of oxygen at the SS/biofilm interface which can be indicated by considering the Nernst equation [58]. It predicts that production of oxygen would increase the electrode potential and vice versa. However, this process could not explain solely the potential ennoblement. The depletion of $\mathrm{O}_{2}$ at the SS/biofilm interface is connected to the production of $\mathrm{H}_{2} \mathrm{O}_{2}$, and other reactive oxygen species (ROS), through the aerobic microbial activities [16, 17], resulting in potential ennoblement. In a previous study, the depletion of $\mathrm{O}_{2}$ and enrichment of $\mathrm{H}_{2} \mathrm{O}_{2}$ were obtained at the vicinity of SS surface using a biomimetic biofilm [59]. Results showed a potential ennoblement similar to that observed in natural media which may be explained by the fact that $\mathrm{H}_{2} \mathrm{O}_{2}$ is a stronger oxidizer [60].

The most plausible explanation consists in an indirect action of diatoms on OCP by providing the photosynthetic metabolic product $\left(\mathrm{O}_{2}\right)$ to other heterotrophic microorganisms present in the biofilm. This explanation was provided by Ishihara and Tsujikawa $[61,62]$ who examined the evolution of OCP values of SS upon a successive immersion in two different media. In the first media, the SS samples were immersed in natural seawater for several days in a way that OCP ennoblement did not significantly exceed values around $+100 \mathrm{mV} / \mathrm{SCE}$. The SS samples were then transferred to the second medium, a diatom-enriched solution in which ennoblement reached values near $+400 \mathrm{mV} / \mathrm{SCE}$. The authors showed that the latter medium (enriched with diatoms) did not lead, solely, to a significant increase of OCP, suggesting that both media are required to reproduce the ennoblement observed in natural conditions. These relevant findings suggest that the ennoblement is the result of a combined action of diatoms and bacteria. Diatoms, through their photosynthetic metabolic activities, provide $\mathrm{O}_{2}$ to heterotrophic bacteria, also present in the biofilm, to be used in the different aerobic metabolic processes, including biogenic formation of $\mathrm{H}_{2} \mathrm{O}_{2}$, as described above. According to the same authors, the ennoblement did not occur in the diatom-enriched medium because diatoms are not able to adhere to the SS surface without a previous surface colonization and adhesion of bacteria.

In our study, it appears that diatoms may be in a direct contact with SS surface (see Figures 1 and 4). The ability of diatoms to adhere to surfaces in the absence of bacteria has been also observed elsewhere [8]. However, it must be kept in mind that the latter study has been conducted in the laboratory under controlled conditions with absence or presence of bacteria. According to Wahl [63], in natural systems, the pattern of bacteria colonizing surfaces before diatoms is either due to their higher relative abundance in the immigrant pool [64] or because they facilitate diatom attachment [65]. Furthermore, it has been reported that the role of bacteria is variable wherein bacteria may facilitate algal attachment if the base material is hydrophilic or has no effect and even inhibit algal attachment if the base material is hydrophobic [64]. Therefore, the type of surface along with the type of bacterial community will influence the bacteriadiatom interactions in the natural environment which will in turn influence the process of ennoblement. Thus, the hypothesis of a combined action of diatoms and bacteria is promising and the question clearly deserves further investigation, as the mechanism of interaction between bacteria and diatoms, from the microbiological point of view, remains not fully understood $[66,67]$.

The complexity of this process is inherent in the multiplicity of parameters influencing the interaction between diatoms and bacteria especially at the SS/biofilm interface. Although other parameters related to the immersion conditions (temperature, location, etc.) are also relevant, our results provide a promising connection between ennoblement and diatom fouling and are particularly important in biofouling and related issues. From an ecology perspective, the interaction of 
diatoms with SS may be extended to other natural or artificial substrata to provide insights into the fate and behavior of diatoms in these specific conditions and to evaluate the impacts on the surrounding ecosystem.

\section{Conclusion}

In this article, a thorough analysis of diatom community is performed on biofilms formed on SS materials upon exposure in a natural freshwater ecosystem (Oise River). ESEM images revealed the dominance of prostrate growth forms such as Cocconeis and Amphora in the six-monthold biofilm (initial colonizers), regardless of the SS type, suggesting their strong attachment capability and tolerance to variable environmental conditions. Both pennate and centric species were dominant on $316 \mathrm{~L}$ and 254SMO types, while only pennate species were dominant on 304L.

Regarding the behavior of SS upon natural exposure and the development of diatom-enriched biofilms, it appears that the ennoblement observed is due to biogenic production of $\mathrm{H}_{2} \mathrm{O}_{2}$ and potentially may involve diatoms, probably through a combined action with heterotrophic bacteria.

\section{Conflicts of Interest}

The authors declare that there are no conflicts of interest regarding the publication of this paper.

\section{Acknowledgments}

The authors thank Dr. D. Aouali for his strong involvement in the present work and Professor K. E. Cooksey (Environmental Biotechnology Consultants, Manhattan, USA) for fruitful discussion and acknowledge SAPC Division (UTC, France) for surface characterizations. Caroline Richard and Jessem Landoulsi acknowledge the support of the "Mission Interministérielle et Interrégionale de l'Aménagement du Territoire du Bassin Parisien (MIIAT-BP)" and the "Conseil Régional de Picardie" in the framework of BIOCORYS Project; Smita Mitbavkar acknowledges the support of CSIRNIO (no. 6039).

\section{References}

[1] P. J. Molino and R. Wetherbee, "The biology of biofouling diatoms and their role in the development of microbial slimes," Biofouling, vol. 24, no. 5, pp. 365-379, 2008.

[2] F. E. Round, R. M. Crawford, and M. DG, The Diatom: Biology and Morphology of the Genera, Cambridge University Press, Cambridge, UK, 1990.

[3] K. Becker, "Detachment studies on microfouling in natural biofilms on substrata with different surface tensions," International Biodeterioration and Biodegradation, vol. 41, no. 1, pp. 93100, 1998 .

[4] M. E. Callow, "Fouling algae from 'in-service' ships," Botanica Marina, vol. 29, no. 4, pp. 351-358, 1986.

[5] M. E. Callow and R. L. Fletcher, "Special issue marine biofouling and corrosion the influence of low surface energy materials on bioadhesion-a review," Inter Biodeter Biodeg, vol. 34, pp. 333$348,1994$.
[6] M. Camps, A. Barani, G. Gregori et al., "Antifouling coatings influence both abundance and community structure of colonizing biofilms: a case study in the Northwestern Mediterranean Sea," Applied and Environmental Microbiology, vol. 80, no. 16, pp. 4821-4831, 2014.

[7] F. Cassé and G. W. Swain, “The development of microfouling on four commercial antifouling coatings under static and dynamic immersion," International Biodeterioration and Biodegradation, vol. 57, no. 3, pp. 179-185, 2006.

[8] K. E. Cooksey, "A requirement for calcium in the adhesion of a fouling diatom to glass," Applied and Environmental Microbiology, vol. 41, pp. 1378-1382, 1981.

[9] B. Cooksey, K. E. Cooksey, C. A. Miller, R. W. Rubin, and D. Webster, "The attachment of microfouling diatoms," in Marine Biodeterioration: An Interdisciplinary Study, J. D. Costlow and R. C. Tipper, Eds., pp. 167-171, Naval Institute Press, Annapolis, Md, USA, 1984.

[10] R. L. Fletcher, "Brief review of the role of marine algae in biodeterioration," International Biodeterioration, vol. 24, no. 3, pp. 141-152, 1988.

[11] K. Z. Hunsucker, A. Koka, G. Lund, and G. Swain, "Diatom community structure on in-service cruise ship hulls," Biofouling, vol. 30, no. 9, pp. 1133-1140, 2014.

[12] S. Patro, D. Adhavan, and S. Jha, "Fouling diatoms of Andaman waters and their inhibition by spinal extracts of the sea urchin Diadema setosum (Leske, 1778)," International Biodeterioration and Biodegradation, vol. 75, pp. 23-27, 2012.

[13] S. Sommer, A. Ekin, D. C. Webster et al., "A preliminary study on the properties and fouling-release performance of siloxanepolyurethane coatings prepared from poly(dimethylsiloxane) (PDMS) macromers," Biofouling, vol. 26, no. 8, pp. 961-972, 2010.

[14] F. Mansfeld, "The interaction of bacteria and metal surfaces," Electrochimica Acta, vol. 52, no. 27, pp. 7670-7680, 2007.

[15] B. J. Little, J. S. Lee, and R. I. Ray, "The influence of marine biofilms on corrosion: a concise review," Electrochimica Acta, vol. 54, no. 1, pp. 2-7, 2008.

[16] J. Landoulsi, K. El Kirat, C. Richard, D. Féron, and S. Pulvin, "Enzymatic approach in microbial-influenced corrosion: a review based on stainless steels in natural waters," Environmental Science and Technology, vol. 42, no. 7, pp. 2233-2242, 2008.

[17] J. Landoulsi, K. E. Cooksey, and V. Dupres, "Review-Interactions between diatoms and stainless steel: focus on biofouling and biocorrosion," Biofouling, vol. 27, no. 10, pp. 1105-1124, 2011.

[18] F. E. Round, "A diatom assemblage living below the surface of intertidal sand flats," Marine Biology, vol. 54, no. 3, pp. 219-223, 1979.

[19] A. Tuji, "Observation of developmental processes in loosely attached diatom (Bacillariophyceae) communities," Phycological Research, vol. 48, no. 2, pp. 75-84, 2000.

[20] S. Mitbavkar and A. C. Anil, "Seasonal variations in the fouling diatom community structure from a monsoon influenced tropical estuary," Biofouling, vol. 24, no. 6, pp. 415-426, 2008.

[21] J. S. Patil and A. C. Anil, "Biofilm diatom community structure: influence of temporal and substratum variability," Biofouling, vol. 21, no. 3-4, pp. 189-206, 2005.

[22] L. H. Sweat and K. B. Johnson, "The effects of fine-scale substratum roughness on diatom community structure in estuarine biofilms," Biofouling, vol. 29, no. 8, pp. 879-890, 2013.

[23] K. A. Zargiel and G. W. Swain, "Static vs dynamic settlement and adhesion of diatoms to ship hull coatings," Biofouling, vol. 30, no. 1, pp. 115-129, 2014. 
[24] K. A. Zargiel, J. S. Coogan, and G. W. Swain, "Diatom community structure on commercially available ship hull coatings," Biofouling, vol. 27, no. 9, pp. 955-965, 2011.

[25] B. Biggs and C. Kilroy, "Identification guide to common periphyton in New Zealand streams and rivers," in Stream Periphyton Monitoring Manual, The New Zealand Ministry for the Environment, NIWA Christchurch, New Zealand, 2000.

[26] R. M. Crawford, "The fine structure of the frustule of melosira varians C. A. Agardh," British Phycological Journal, vol. 6, no. 2, pp. 175-186, 1971.

[27] C. Gopinathan, "A systematic account of the littoral diatoms of the southwest coast of India," Journal of the Marine Biological Association of India, vol. 26, pp. 1-31, 1984.

[28] Z. Levkov, K. Caput Mihalić, and L. Ector, "A taxonomical study of rhoicosphenia grunow (Bacillariophyceae) with a key for identification of selected taxa," Fottea, vol. 10, no. 2, pp. 145-200, 2010.

[29] N. Washizu, Y. Katada, and T. Kodama, "Role of H2O2 in microbially influenced ennoblement of open circuit potentials for type 316L stainless steel in seawater," Corrosion Science, vol. 46, no. 5, pp. 1291-1300, 2004.

[30] C. Marconnet, C. Dagbert, M. Roy, and D. Féron, "Stainless steel ennoblement in freshwater: from exposure tests to mechanisms," Corrosion Science, vol. 50, no. 8, pp. 2342-2352, 2008.

[31] L. L. Machuca, R. Jeffrey, S. I. Bailey et al., "Filtration-UV irradiation as an option for mitigating the risk of microbiologically influenced corrosion of subsea construction alloys in seawater," Corrosion Science, vol. 79, pp. 89-99, 2014.

[32] C. Hudon and E. Bourget, "Initial Colonization of Artificial Substrate: Community Development and Structure Studied by Scanning Electron Microscopy," Canadian Journal of Fisheries and Aquatic Sciences, vol. 38, no. 11, pp. 1371-1384, 1981.

[33] P. J. Molino, E. Campbell, and R. Wetherbee, "Development of the initial diatom microfouling layer on antifouling and foulingrelease surfaces in temperate and tropical Australia," Biofouling, vol. 25, no. 8, pp. 685-694, 2009.

[34] M. A. Harper and J. F. Harper, "Measurements of diatom adhesion and their relationship with movement," British Phycological Bulletin, vol. 3, no. 2, pp. 195-207, 1967.

[35] C. D. McIntire and B. L. Wulff, "A laboratory method for the study of marine benthic diatoms," Limnology and Oceanography, vol. 14, no. 5, pp. 667-678, 1969.

[36] B. Moss, "Adaptations of epipelic and epipsammic freshwater algae," Oecologia, vol. 28, no. 1, pp. 103-108, 1977.

[37] J. A. Hellebust and J. Lewin, "Heterotrophic nutrition," in The Biology of Diatoms, D. Werner, Ed., pp. 169-198, Botanical Monographs Blackwell Scientific Publications, Oxford, UK, 1977.

[38] C. Hudon and E. Bourget, "The effect of light on the vertical structure of epibenthic diatom communities," Botanica Marina, vol. 26, no. 7, pp. 317-330, 1983.

[39] N. Gómez and M. Licursi, “The pampean diatom index (IDP) for assessment of rivers and streams in Argentina," Aquatic Ecology, vol. 35, no. 2, pp. 173-181, 2001.

[40] N. Tanaka, "Adhesive strength of epiphytic diatoms on various seaweeds," Bulletin of the Japanese Society of Scientific Fisheries, vol. 52, pp. 817-821, 1986.

[41] W. R. Hill, B. J. Roberts, S. N. Francoeur, and S. E. Fanta, "Resource synergy in stream periphyton communities," Journal of Ecology, vol. 99, no. 2, pp. 454-463, 2011.
[42] C. McIntire, "Structural characteristics of benthic algal communities in laboratory streams," Hydrobiologia, vol. 27, pp. 559-570, 1968.

[43] S. Mitbavkar and A. Anil, "Diatom colonization on stainless steel panels in estuarine waters of Goa, west coast of India," Indian Journal of Marine Sciences, vol. 29, no. 3, pp. 273-276, 2000.

[44] N. Munteanu and E. J. Maly, "The effect of current on the distribution of diatoms settling on submerged glass slides," Hydrobiologia, vol. 78, no. 3, pp. 273-282, 1981.

[45] N. R. Silvester and M. A. Sleigh, "The forces on microorganisms at surfaces in flowing water," Freshwater Biology, vol. 15, no. 4, pp. 433-448, 1985.

[46] R. W. Anyam, "Distribution of epilithic diatoms in the River Ithon (U.K.)," Nigerian Journal of Botany, vol. 3, pp. 119-131, 1990.

[47] W. H. Dickinson, Z. Lewandowski, and R. D. Geer, "Evidence for surface changes during ennoblement of type 316L stainless steel: dissolved oxidant and capacitance measurements," Corrosion, vol. 52, no. 12, pp. 910-920, 1996.

[48] J. Liao, H. Fukui, T. Urakami, and H. Morisaki, "Effect of biofilm on ennoblement and localized corrosion of stainless steel in fresh dam-water," Corrosion Science, vol. 52, no. 4, pp. 1393 1403, 2010.

[49] K. Xu, S. C. Dexter, and G. W. Luther, "Voltammetric microelectrodes for biocorrosion studies," Corrosion, vol. 54, no. 10, pp. 814-823, 1998.

[50] H. Amaya and H. Miyuki, "Development of accelerated evaluation method for microbially influenced corrosion resistance of stainless steels," Corrosion Engineering, vol. 44, p. 123, 1995.

[51] H. Amaya and H. Miyuki, "Mechanism of microbially influenced corrosion on stainless steels in natural seawater and effect of surface treatment to corrosion resistance," Corrosion Engineering, vol. 46, no. 8, pp. 481-490, 1997 (Japanese).

[52] H. Amaya and H. Miyuki, Laboratory Reproduction of Potential Ennoblement of Stainless Steels in Natural Seawater, Corrosion NACE Houston, Houston, Tex, USA, 1999.

[53] I. Dupont, D. Féron, and G. Novel, "Effect of glucose oxidase activity on corrosion potential of stainless steels in seawater," International Biodeterioration and Biodegradation, vol. 41, no. 1, pp. 13-18, 1998.

[54] J. Landoulsi, M. J. Genet, C. Richard, K. El Kirat, P. G. Rouxhet, and S. Pulvin, "Ennoblement of stainless steel in the presence of glucose oxidase: Nature and role of interfacial processes," Journal of Colloid and Interface Science, vol. 320, no. 2, pp. 508519, 2008.

[55] J. Landoulsi, C. Dagbert, C. Richard et al., "Enzyme-induced ennoblement of AISI 316L stainless steel: focus on pitting corrosion behavior," Electrochimica Acta, vol. 54, no. 28, pp. 7401-7406, 2009 (Japanese).

[56] S. Maruthamuthu, M. Eashwar, S. Sebastin Raja, and K. Balakrishnan, "Effects of microfouling and light/dark regimes on the corrosion potentials of two stainless alloys in seawater," Biofouling, vol. 7, no. 4, pp. 257-265, 1993.

[57] S. Maruthamuthu, G. Rajagopal, S. Sathianarayannan, M. Eashwar, and K. Balakrishnan, "A photoelectrochemical approach to the ennoblement process: proposal of an adsorbed inhibitor theory," Biofouling, vol. 8, no. 3, pp. 223-232, 1995.

[58] A. J. Bard and L. R. Faulkner, Electrochemical Methods: Fundamentals and Application, Wiley, New York, NY, USA, 2nd edition, 2001. 
[59] J. Landoulsi, K. El Kirat, C. Richard, R. Sabot, M. Jeannin, and S. Pulvin, "Glucose oxidase immobilization on stainless steel to mimic the aerobic activities of natural biofilms," Electrochimica Acta, vol. 54, no. 1, pp. 133-139, 2008.

[60] M. Pourbaix, Atlas d'Equilibres Electrochimiques, GauthierVillars, Paris, France, 1963.

[61] Y. Ishihara and S. Tsujikawa, "Effect of diatoms on ennoblement of electrode potential for stainless steels in natural sea water," Corrosion Engineering, vol. 47, no. 4, pp. 260-266, 1998.

[62] Y. Ishihara and S. Tsujikawa, "Effect of bacteria combined with diatom on ennoblement of electrode potential for stainless steels in natural sea water," Corrosion Engineering, vol. 48, no. 8, pp. 520-527, 1999.

[63] M. Wahl, "Marine epibiosis. I. Fouling and antifouling: some basic aspects," Marine Ecology Progress Series, vol. 58, pp. 175$189,1989$.

[64] B. Gawne, Y. Wang, K. D. Hoagland, and M. R. Gretz, "Role of bacteria and bacterial exopolymer in the attachment of Achnanthes longipes (Bacillariophyceae)," Biofouling, vol. 13, no. 2, pp. 137-156, 1998.

[65] C. G. Peterson and R. J. Stevenson, "Substratum conditioning and diatom colonization in different current regimes," Journal of Phycology, vol. 25, no. 4, pp. 790-793, 1989.

[66] L. Khandeparker, P. M. D'costa, A. C. Anil, and S. S. Sawant, "Interactions of bacteria with diatoms: influence on natural marine biofilms," Marine Ecology, vol. 35, no. 2, pp. 233-248, 2014.

[67] B. Wigglesworth-Cooksey and K. E. Cooksey, "Use of fluorophore-conjugated lectins to study cell-cell interactions in model marine biofilms," Applied and Environmental Microbiology, vol. 71, no. 1, pp. 428-435, 2005. 

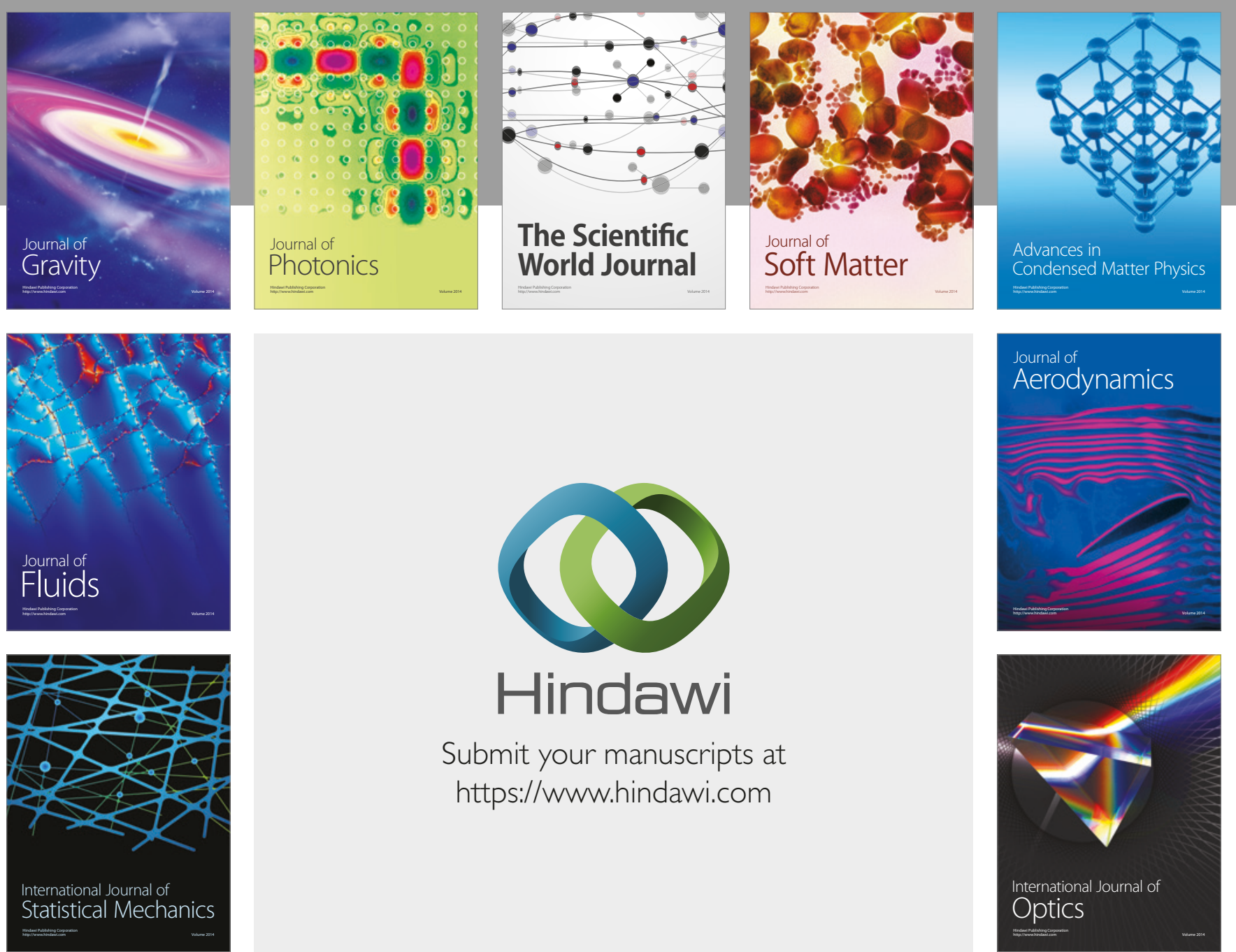

Submit your manuscripts at

https://www.hindawi.com
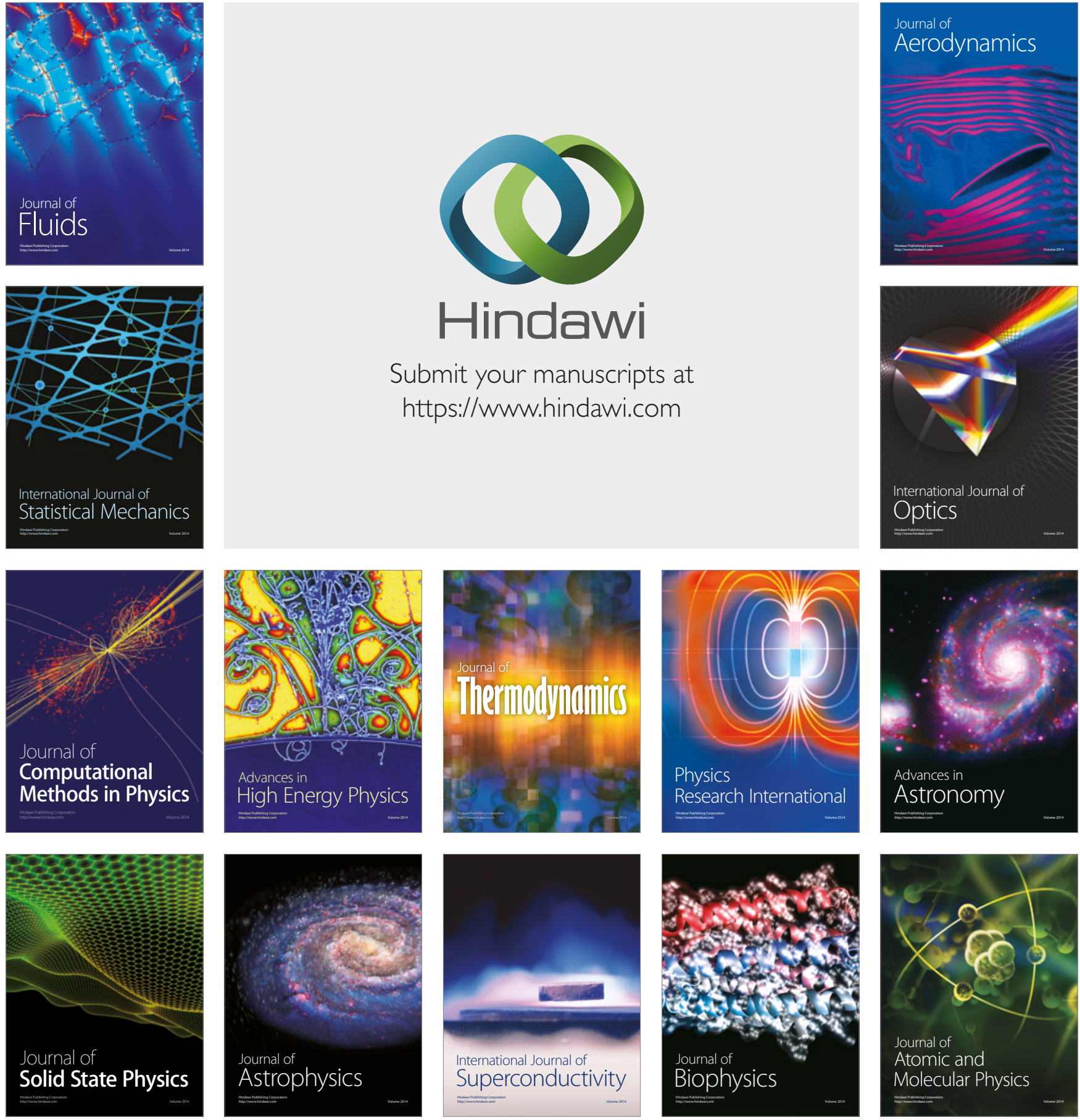